Civil Engineering Construction

Design and Management 


\section{Other titles of interest to Civil Engineers}

Soil Mechanics - Principles and Practice, Second edition

G. E. Barnes

Structural Mechanics, Second edition

J. Cain and R. Hulse

Timber - Structure, Properties, Conversion and Use, Seventh Edition

H. E. Desch and J. M. Dinwoodie

Understanding Hydraulics, Second edition

Les Hamill

Civil Engineering Materials, Fifth Edition

Edited by N. Jackson and R. K. Dhir

Reinforced Concrete Design, Fifth Edition

W. H. Mosley and J. H. Bungey

Reinforced Concrete Design to Eurocode 2

W. H. Mosley, R. Hulse and J. H. Bungey

Plastic Methods for Steel and Concrete Structures, Second Edition

S. S. J. Moy

Highway Traffic Analysis and Design, Third Edition

R. J. Salter and H. B. Hounsell

Civil Engineering Quantities, Sixth Edition

I. H. Seeley

Understanding Structures, Second Edition

Derek Seward

Surveying for Engineers, Third Edition

J. Uren and W. F. Price

Fluid Mechanics

Martin Widden

Engineering Hydrology, Fifth Edition

E. M. Wilson 


\title{
Civil Engineering Construction Design and Management
}

\author{
Dene R. Warren \\ BSc, CEng MICE, MIStructE \\ Nene College of Higher Education, Northampton
}




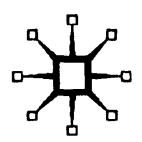

All rights reserved. No reproduction, copy or transmission of this publication may be made without written permission.

No paragraph of this publication may be reproduced, copied or transmitted save with written permission or in accordance with the provisions of the Copyright, Designs and Patents Act 1988, or under the terms of any licence permitting limited copying issued by the Copyright Licensing Agency, 90 Tottenham Court Road, London W1T 4LP.

Any person who does any unauthorised act in relation to this publication may be liable to criminal prosecution and civil claims for damages.

The author has asserted his right to be identified as the author of this work in accordance with the Copyright, Designs and Patents Act 1988.

\section{Published by}

PALGRAVE

Houndmills, Basingstoke, Hampshire RG21 6XS and 175 Fifth Avenue, New York, N. Y. 10010

Companies and representatives throughout the world

PALGRAVE is the new global academic imprint of

St. Martin's Press LLC Scholarly and Reference Division and

Palgrave Publishers Ltd (formerly Macmillan Press Ltd).

ISBN 978-0-333-63682-4

ISBN 978-1-349-13727-5 (eBook)

DOI 10.1007/978-1-349-13727-5

This book is printed on paper suitable for recycling and made from fully managed and sustained forest sources.

A catalogue record for this book is available from the British Library.
$\begin{array}{llllllll}10 & 9 & 8 & 7 & 6 & 5 & 4 & 3\end{array}$
$\begin{array}{llllllll}09 & 08 & 07 & 06 & 05 & 04 & 03 & 02\end{array}$ 


\section{Contents}

Preface

Acknowledgements

vii

1 Contract Administration

$1.1 \quad$ Pre-Contract Stage

1.2 Feasibility Study

1.3 Authorisation to Build

1.4 Conditions of Contract 5

$\begin{array}{lll}1.5 & \text { Contract Documents } & 9\end{array}$

$\begin{array}{lll}1.6 & \text { Management Structures } & 12\end{array}$

$\begin{array}{lll}1.7 & \text { Basis for Payment } & 15\end{array}$

$\begin{array}{ll}1.8 \text { Letting the Contract } & 17\end{array}$

$\begin{array}{lll}1.9 & \text { The Future } & 18\end{array}$

2 Control

2.1 Client Control 21

2.2 Contractor Control 22

2.3 Financial Control 23

2.4 Quality Control 26

2.5 Quality Assurance 26

2.6 Programming 31

3 Safety $\quad 47$

3.1 Statute and Common Law in Safety Matters 48

3.2 Health and Safety at Work Act 1974

3.3 Control of Substances Hazardous to Health 1989

3.4 European Law 52

3.5 New Engineering Contract 54

3.6 Case Studies 54

4 Ground Water Control 56

4.1 Introduction 56

4.2 Temporary Solutions 58

4.3 Permanent Solutions 71

$\begin{array}{lll}4.4 & \text { Overview } & 80\end{array}$ 
5 Earthworks $\quad 85$

$\begin{array}{lll}5.1 & \text { Plant } & 85\end{array}$

$\begin{array}{lll}5.2 & \text { Types of Earthworks } & 93\end{array}$

$\begin{array}{lr}5.3 \quad \text { Management of Earthworks } & 100\end{array}$

$\begin{array}{lll}5.4 & \text { Slope Stability } & 113\end{array}$

6 Foundation Construction and Design 120

$\begin{array}{ll}6.1 & 120\end{array}$

$\begin{array}{lll}6.2 & \text { Soil Properties } & 124\end{array}$

6.3 Pad Design and Construction 131

$\begin{array}{ll}6.4 & \text { Pile Design and Construction } \\ 6.50\end{array}$

$\begin{array}{ll}6.5 & \text { Foundation Design } \\ 6.6 & 150\end{array}$

$\begin{array}{lll}6.6 & \text { Ground Improvement } & 156\end{array}$

$\begin{array}{ll}6.7 & 160\end{array}$

$7 \quad$ Retaining Walls and Deep Basements 165

7.1 Construction of Retaining Walls 165

7.2 Design of a Retaining Wall

$\begin{array}{lll}7.3 & 176\end{array}$

$\begin{array}{lll}7.4 & \text { Watertight Basements } & 181\end{array}$

8 Superstructures 186

8.1 Long Span Structures

187

8.2 Medium Rise Structures 196

$\begin{array}{lll}8.3 & 206\end{array}$

9 Drainage $\quad 212$

$\begin{array}{lll}9.1 & 212\end{array}$

\begin{tabular}{ll}
9.2 & Structural Design of Drainage \\
\hline
\end{tabular}

\begin{tabular}{ll}
9.3 & Drainage Construction \\
\hline
\end{tabular}

$\begin{array}{lll}9.4 & \text { Trenchless Technology } & 230\end{array}$

10 Road Pavements $\quad 234$

$\begin{array}{lll}10.1 & \text { The Pavement } & 235\end{array}$

$\begin{array}{lll}10.2 & \text { Road Building Material } & 238\end{array}$

10.3 Pavement Design 244

$\begin{array}{lll}10.4 \text { Construction } & 250\end{array}$

$\begin{array}{lr}\text { Index } & 254\end{array}$ 


\section{Preface}

This book is written for students on Civil Engineering degree and diploma courses but may also be useful as a reference text for practising Engineers in the design office and on site.

The structure is based on the BTEC unit Civil Engineering Construction A (level $\mathrm{H}$ ) but its contents have been developed far beyond into practical design and management based on the author's wide experience of industry. The book is a compendium of basic civil engineering construction methods brought together with well known design and management techniques. Wherever possible a summary of design options is presented with case studies and examples to give the reader a feel for the correct design solution. The book is intended to be a gateway to civil engineering, giving the reader an overview of the processes involved and showing the way into many other texts referenced throughout the book.

The book covers a wide range of areas within construction, from management and safety to design and construction, from earthworks and ground water control through to building superstructures and roads. The book begins by reviewing the contractual aspects of pre-construction and construction stages bringing in the options of Client and Engineer choice. Principal contractual and management structures are described and compared, together with the more commonly used financial arrangements. This is developed to illustrate how civil engineering projects can be effectively planned, managed and controlled. Safety is considered in some depth from both the historical viewpoint and in examining today's responsibilities. Fundamental techniques of groundwater control and excavation are reviewed and developed into management and design aspects by the use of case studies and examples. Structures are developed in a similar manner to look at foundations, retaining wall and basement construction and design. Commonly used design techniques are demonstrated with plenty of examples. Different methods of superstructure construction are reviewed and compared giving simple performance and cost comparisons. The stability of structures is also considered with examples. The book concludes with a brief but comprehensive look at drainage, road construction and design.

The author has endeavoured to use up-to-date source material wherever possible. Much information has been gained from current standards, the technical press and direct from industry. Whilst this is the case, however, it must be stated that standards and design methods are frequently updated and the reader must check that the information used from this book is up-to-date at the time.

Dene Warren 


\section{Acknowledgements}

I am indebted to all the following people, but most of all to my wife, Linda, who has given me enormous support in the writing of this book. I am very grateful to Roger E Padwick CEng (retired), formerly with Brand Leonard Consulting Engineers of Chelmsford, who has not only taken the time and trouble to proofread this book to his usual high standard, but who has also been a guiding light and mentor to my career. I have had a great deal of help and assistance from people in the construction industry, too numerous to detail here, but special thanks are given to the following for their kind permission to reproduce information, diagrams and tables from their own publications. Specific items of permission are acknowledged within the text.

- ARC Pipes, Mells Road, Mells, Frome, Somerset BA11 3PD

- Birchwood Concrete Products Ltd, Birchwood Way, Cotes Park Industrial Estate, Somercotes, Derbyshire DE55 4NH

- British Standards Institution. Extracts from BS 8102:1990 are reproduced with the permission of BSI. Complete copies can be obtained by post from BSI Customer Services, 389, Chiswick High Road, London W4 4AL

- British Steel Plc PO Box 1, Scunthorpe South Humberside DN16 1BP

- Fondedile Foundations Ltd, Rigby Lane, off Swallowfield, Hayes Middlesex UB3 1ET

- Health and Safety Executive, Statistical Services Unit, Trinity Road, Bootle, Merseyside, L20 7HE

- HMSO Publications, Room 2b St Crispins, Duke street, Norwich, NR3 1PD

- Keller Ltd, Thorp Arch Trading Estate, Wetherby, West Yorkshire LS23 7BJ

- The Meteorological Office

- Liebherr - Great Britain Ltd, Travellers Lane, Welham Green, Hatfield, Herts

- The Editor, New Civil Engineer, Thomas Telford House, 1, Heron Quay, London E14 4JD

- Roger Bullivant Ltd, Walton Road, Drakelow, Burton on Trent, Staffordshire DE15 9UA

- Space Decks Lid, Chard, Somerset TA20 2AA

- Transport and Road Research Laboratory, Crowthorne, Berkshire.

- Westpile Ltd, Dolphin Bridge House, Rockingham Road, Uxbridge UB8 2UB 